\title{
AS PERFORMANCES DE CASSANDRA EM TROIANAS DE EURÍPIDES
}

\author{
CHRISTIAN WERNER* \\ Faculdade de Filosofia, Letras e Ciências Humanas \\ Universidade de São Paulo
}

\begin{abstract}
RESUMO: Na Atenas do século V a. C., há uma distância entre os discursos políticos, como a oração fúnebre, e o discurso trágico, mas essa diferença foi borrada em muitos dos últimos trabalhos críticos sobre a tragédia ática. O episódio de Cassandra em Troianas de Eurípides é um exemplo eloqüente do oposto, ou seja, a utilização, pela tragédia, da ideologia da polis para explicitar a sua alteridade. Cassandra movimenta-se entre uma tentativa de construir um discurso consistente sobre a fama imorredoura de Tróia e a performance de seu próprio casamento, o qual a vincula às vicissitudes de sua família e à sua própria história como profetisa.
\end{abstract}

PALAVRAS-CHAVE: tragédia; Eurípides; Troianas; oração fúnebre ateniense.

Uma opinião bastante comum sobre Eurípides é de que nas suas peças encontramos, separados como a água e o azeite, cenas da mais intensa comoção - o que levou Aristóteles a mencioná-lo como o mais trágico dos poetas (Poética 1453-28-30) - e falas exageradamente racionais, permeadas por argumentos fundamentados no discurso sofístico coevo (LESKY, 1991: 391). Curiosamente, uma reprodução desse esquematismo hermenêutico (emoção x racionalismo) ${ }^{1}$ é encontrada, de modo diferenciado, em diversas análises que se debruçam não só sobre os outros tragediógrafos, como também sobre a tragédia do séc. V como um todo: ou bem determinada tragédia é enfocada como um mecanismo de cunho didático, marcada, na sua essência, pela identidade radicalmente política da polis ateniense, ou bem ela é apresentada como um construto estético cuja função precípua seria produzir, nos espectadores, uma alta carga de emoções. ${ }^{2}$

Escolhemos um episódio de Troianas, de Eurípides, para procurar mostrar como as opiniões esboçadas acima estão equivocadas no seu extremismo. Quanto 
à tragédia em questão, são dois os eixos de leitura mais comumente partilhados pelos seus críticos. A vertente crítica que se preocupa, em primeiro lugar, com sua estrutura interna, destaca o sofrimento da mater dolorosa Hécuba como fio condutor que interligaria uma série de episódios mais ou menos desconexos. Os intérpretes ávidos pela identificação de referentes políticos externos, por sua vez, lêem na peça admoestações de Eurípides a seus concidadãos atenienses, condenando-os pelo massacre de Melos, em 416, e incitando-os a interromperem a expedição contra a Sicília, que ocorreria alguns meses depois da encenação da peça. O episódio de Cassandra, especialmente a interpretação do epitáfio por ela enunciado, nos indicam, porém, uma chave interpretativa que dá conta, de forma mais eficiente, da peça como um todo.

Algo sobressai no episódio de Cassandra, se compararmos os discursos aqui produzidos com os dos outros episódios: suas falas não originam nem uma altercação nem um diálogo, mas, por parte de Hécuba, do coro e de Taltíbio, uma rejeição sumária. Ora, o caráter monológico é uma das muitas - e não menos importantes - características que a fala central de Cassandra (353-405) compartilha com a oração fúnebre ateniense, ${ }^{3}$ de sorte que, como mostraremos abaixo, tanto formalmente quanto, sobretudo, tematicamente, tais versos podem ser lidos como um discurso homólogo àqueles que, durante a maior parte do século $\mathrm{V}$ (e quase até o final do século seguinte), eram realizados, anualmente, no Cerâmico.

O trecho que contém o epitáfio tem sido lido como a parte fria, excessivamente racional da cena, ou então como o trecho "são" que explicaria a alegria "louca" da monódia inicial (308-41). As etiquetas que o discurso costuma receber são peremptórias: árida comparação entre gregos e troianos que talvez venha da sofística (Mason 1959: 80-93); reprodução dos valores do epitáfio (Harder 1993: 228-29) e da moralidade convencional (Scodel 1980: 368).

Constituindo-se em um monólogo, a oração fúnebre distancia-se do discurso trágico, no qual está presente o diálogo que não estatui uma verdade unívoca, mas figura aspectos diversos, amiúde contraditórios, de uma realidade. ${ }^{4}$ Todavia, ao contrário do epitaphios logos, que cria discursivamente uma idealidade distante da realidade, sendo que a percepção dessa idealidade permite aos ouvintes do discurso uma certa reação prazerosa (Loraux 1994: 281-83), ao monólogo de Cassandra se sucedem apenas manifestações de desagrado, embora também ela procure apresentar uma situação - possivelmente - idealizada (365-66; 385-86).

Enquanto monólogo, a oração fúnebre encontra-se mais próxima da palavra-elogio ou da palavra-memória (Loraux 1994: 38), marca de uma sociedade 
aristocrática, do que da palavra-diálogo, própria de uma conjuntura democrática. As diferenças entre a palavra-memória das sociedades aristocráticas e aquela enunciada na Atenas democrática, porém, são grandes. O poeta, em uma sociedade aristocrática, era o emissor privilegiado da palavra que conferia glória imorredoura a ações e agentes. Elogiavam-se, sobretudo, indivíduos e ações singulares. Na oração fúnebre, não apenas entra em cena a prosa, mas a poesia e o poeta são expressamente rejeitados, e o orador, alguém prestigiado entre os cidadãos, além de ser escolhido democraticamente, realiza um louvor da coletividade, da cidade (Loraux 1994: 38).

Quanto a Cassandra, ela compartilha de características próprias do poeta e, claro, do adivinho - que, na epopéia, inspirado pelas Musas, é capaz de expressar o passado, o presente e o futuro. Em Troianas, acreditando-se portadora da verdade (424-30), a própria Cassandra se faz oradora e pretende, como um poeta, não apenas elogiar a cidade e seus habitantes em geral, mas também mencionar ações e personagens individualizados cuja glória nunca será esquecida $(397,399)$.

Todavia, embora Cassandra tenha recebido de Apolo o dom mântico, a tradição diz que sua palavra divina nunca recebe crédito. É nesse contexto que devemos entender a introdução do epitáfio da profetisa, quando ela afirma falar "tendo o deus em mim, todavia (...) fora de baqueumas" (366-67), ${ }^{5}$ ou seja, longe do estado de possessão dionisíaca? ${ }^{6}$ Posêidon é o primeiro a representar Cassandra como louca (42). Em seguida, Hécuba também se queixa da loucura da filha (169$72,306-07,348-50$ ); de fato, qualquer atitude de Cassandra que não seja contígua às da mãe e às do coro é censurada como sinal de possessão.

A mais assombrosa pretensão de Cassandra é querer mostrar que Tróia é mais abençoada do que os aqueus (365-66), à medida que pertence à cidade e aos troianos "a mais bela glória" (386). A utilização do termo "abençoado" (makarios) primeiramente remete, todavia, ao auto-propagado e auto-celebrado casamento de Cassandra. Na verdade, a fala central da profetisa dá as razões para o seu canto festivo inicial. Quando Cassandra diz que falará "fora de baqueumas", ela deixa claro que finalizou a performance ritual que marcara a sua entrada em cena.

Rapidamente, porém, o casamento se transmuta em fato guerreiro, agonístico, vingativo. Mesmo antes de Cassandra dizer que falará fora de baqueumas, ela anuncia uma vingança a ser concretizada. Mais adiante, ela então vincula seu casamento à lista que inclui os feitos heróicos de seus irmãos. Como no caso deles, a morte coroará seu ato $(400-02,460)$. 
Não é a realidade percebida por Hécuba e pelo coro o que vislumbra Cassandra. $\mathrm{O}$ ângulo pelo qual descreve os acontecimentos não enfoca nem a destruição de Tróia, nem a morte física dos irmãos e demais homens nem o fato de se dirigir a Argos como mera concubina do rei. Para além da realidade imediata do aniquilamento, o que Cassandra decide evocar é o seu casamento bem-sucedido e a glória da cidade e de seus mais ilustres membros. Todavia, se, para os guerreiros mortos celebrados pela oração fúnebre ateniense, a felicidade - e não há outra provém de um renome eterno auferido graças à imortalidade da cidade (Loraux 1994: 130), Cassandra supera a auto-celebração de Atenas (passada ou presente) no Cerâmico, à medida que não há mais cidade visível a ser celebrada.

Assinale-se que "imortal", o qualificativo da memória e da glória, não é mencionado nesse trecho. Pelo contrário, os versos 365-405 são pontilhados por verbos denotando a morte física, sendo que esses verbos, como a maioria dos verbos do trecho, encontram-se no aoristo. Como anunciadora da glória e da ventura presentes, Cassandra é prima facie narradora de fatos passados, já que o estado atual da cidade, seu presente físico, não interessa à sua tática discursiva. Os verbos que saem desse padrão, verbos no presente e no futuro (futuro: 382, 359-65, 385, 405; presente: $379,394-95)$, configuram, porém, algo significativo. No contexto criado pela profetisa, o futuro é ligado ao passado e vice-versa. $\mathrm{O}$ passado explica um futuro cru e obscuro: como as ações dos irmãos - os feitos guerreiros de Heitor; o casamento glorioso de Páris -, a de Cassandra é uma ação guerreira e portadora de glória. Além disso, o futuro potencializa o passado: as ações de Heitor e Páris não foram vãs nem terminais, pois contribuíram para a conquista da glória que tem seu fechamento, seu coroamento, em Cassandra. No contexto do epitáfio, Cassandra não é a vítima da hubris e da atê de Aias e Agamêmnon, assim como Páris não é vítima de Helena, nem Heitor, uma vítima dos gregos. Não Tróia, mas os aqueus foram vítimas do casamento de Páris. Para Cassandra, seu ato e o de Páris espelham-se perfeitamente. Vinculando-se a seus irmãos, ela evita aparecer como mera vingadora selvagem.

Todavia, no quadro constituído pelo passado e pelo futuro, o presente. Em primeiro lugar, a cerimônia do casamento de Cassandra, prelúdio da vingança futura. O presente construído e mediado por Cassandra instaura-se com um epitalâmio, acompanhado por variáveis sensíveis, como o fogo, a música e a dança, os quais tornam a cena hiperbolicamente presente. Esses sinais visam a transmitir uma alegria que, por sua vez, se contrapõe ao horror e ao desprezo que acompanham a recusa, por parte do coro e de Hécuba, de participarem das bodas. Num segundo momento, porém, esse quadro se transmuta, para além do presente de Tróia destruída, ardendo em fogo, em um presente fora do tempo. As ações descri- 
tas por meio de formas verbais no presente apontam para ações passadas cujos efeitos tangíveis pertencem ao presente e perdurarão para sempre.

Resumindo, a oração fúnebre de Cassandra sintetiza um quadro de ações pretéritas em um contexto de ações futuras, síntese marcada pelo fenômeno da morte. Essas ações são invocadas enquanto geradoras de glória imortal a alguns actantes - troianos -, ou enquanto empecilhos para que outros - gregos - não a obtenham. Cumpre destacar, porém, que, mesmo trazendo ações passadas e futuras e seus efeitos para o presente com vistas a proclamar venturosa a cidade, somente o discurso presente confere àquelas ações e, contigüamente, à cidade, a sua glória. É o uso de formas verbais do presente que comunicam a imortalidade da glória, o que aparece, de forma condensada, na gnoma final (400-02). O tour de force de Cassandra - seu discurso constituindo-se propriamente em uma ação - é melhor medido quando contraposto à autoridade que as outras prisioneiras visam a imprimir à realidade tal qual percebida por elas, para quem uma glória presente da cidade é inconcebível.

Também é próprio da oração fúnebre o pretenso domínio do tempo (Loraux 1994: 23). Em primeiro lugar, o instante da enunciação do discurso encontra-se como que fora do tempo (Loraux 1994: 33). Enquanto o tempo vivido marcado por ações possíveis faz parte da realidade, a oração fúnebre, discurso que veicula uma idealidade distanciada da realidade, instaura o aiôn (Loraux 1994: 342). Além disso, ao buscar a palavra de glória, lembrança eterna, para exorcizar a morte (Loraux 1994: 22 e 41), a oração fúnebre louva a cidade, pois é ela que confere glória imortal aos guerreiros mortos (Loraux, 1994: 132).

Domina uma história, portanto, a representação que a cidade faz de si mesma. Assim, à primeira vista, a diferença principal entre a oração fúnebre e o epitáfio de Cassandra é o peso reduzido que, no segundo, parece ter a cidade enquanto instância prestadora de honra coletiva a seus mortos. Isso se explica, em um primeiro momento, pelo fato da tragédia trabalhar com o mito, que se refere a ações individuais (Loraux 1994: 122; Vernant 1989: 82-3). Além disso, a instância amiúde referida por Cassandra é o oikos, embora, com isso, não seja pretendida uma separação nítida entre oikos e polis. Dessa forma, o discurso de Cassandra assemelha-se, curiosamente, à oração fúnebre do século IV a.C., que mantém o topos do louvor da cidade, mas elogia uma cidade que não é mais a mesma. Cassandra, ao não elogiar diretamente a cidade, evita a evocação de uma realidade não mais existente; louvando as benesses propiciadas pelo oikos, todavia, acaba por elogiar a cidade, instância sem a qual não seriam possíveis as atividades privadas (384-93). ${ }^{\text {? }}$ 
Mas há algo de muito inquietante no epitáfio de Cassandra: Tróia efetivamente não existe mais. Essa é a realidade consternadora que abre o canto introdutório de Hécuba (99-100). Todavia, o quadro temporal esboçado acima revela que, para Cassandra, tanto o uso de temas e táticas da oração fúnebre quanto a menção de Tróia no início do discurso são apenas suportes imaginários para que a profetisa se louve a si mesma. Cassandra necessita de topoi consagrados para explicar por que suas ações - casamento e vingança - são dignas de louvor, vale dizer, heróicas. Para conseguir isso, Cassandra paga um preço: afasta-se dos deuses e de Tróia enquanto (ex-) cidade real. No afã de opor gregos e troianos, ela chega a dizer que faz parte da desonra dos gregos terem morrido "não privados das fronteiras do país nem da pátria altimurada" (375-376). Ora, as marcas de Tróia são justamente seus muros, que irão ruir por completo até o final da tragédia. É claro que Cassandra quer apresentar as ações dos gregos como indignas de louvor, mas o preço que os troianos pagam por sua glória - lutar tendo a honra de defender os muros da cidade - não é alto demais? Cassandra quase diz que é honroso para os troianos terem perdido os muros de sua cidade.

O epitáfio de Cassandra, assim como a oração fúnebre ateniense, apresenta uma versão idealizada da polis. Se ambos driblam a presença real dos mortos para realizar sua estratégia, não há, porém, no final de Troianas, como em Atenas, um belo túmulo e um epigrama versificado (Loraux 1994: 43) para os troianos que morreram ao findar a guerra. Em Tróia não há nada, o que problematiza a lógica da honra heróica do "tudo ou nada" (Vernant 1989: 47) da qual se apropria Cassandra. Ainda que Cassandra ponha a sua ação sob o signo do "tudo" (a glória eterna), conquistado pagando-se um alto preço, a morte, a profetisa dificilmente consegue convencer que para a cidade valha a mesma lógica. Além disso, se nos rituais fúnebres atenienses o repatriamento das cinzas provavelmente remete à celebração de heróis nacionais, protetores das muralhas da polis (Loraux 1994: 58), a auto-heroicização perpetrada por Cassandra é inútil, pois não há mais cidade nem muralha que ela, tendo morrido, possa proteger. Para a cidade que não mais existe, o herói não tem mais valia. Na oração fúnebre, não só a cidade continua a brilhar como única instância viva, embora a morte apareça como único ato, mas a vida de cada cidadão é vivenciada como um dom conferido pela polis (Loraux 1994: 120); na oração fúnebre de Cassandra, os atos valorosos são as ações que coroaram a vida de alguns indivíduos, mas, como também ocorrera nas previsões passadas da profetisa, implicam - ou, no caso de Cassandra, pressupõem - a morte da cidade.

Temos, porém, realmente uma tensão entre a destruição e a glória de Tróia, entre a verdade e um simulacro / idealidade? Se, em um primeiro momento, para 
Hécuba, só o choro preenche a perda dos homens da família e a devastação da cidade, e, para Cassandra, só o puro elogio dos guerreiros e da cidade instaura algo significativo, a própria fala de Cassandra mostra que a glória implica algo negativo e algo positvo - e a fala de Hécuba (466-510) deixa entrever que a desgraça também faz parte de um contexto marcado pelo negativo e pelo positivo. Ambas pretendem apontar apenas para um lado do quadro que Troianas vai esboçando, mas as suas próprias palavras, a formulação do seu discurso indicam algo contrário ao que intencionam retratar. $\mathrm{O}$ discurso de Cassandra acaba alcançando a intemporalidade não porque a glória seja imortal, mas porque ele deixa entrever que qualquer instante de glória e de desgraça faz parte de uma cadeia ilimitada de instantes passados e futuros de glória e desgraça. A oposição nítida entre gregos, desgraçados, e troianos, venturosos, é tão falsa quanto a visão contrária, gregos, venturosos, troianos, desgraçados. Da mesma forma, o choro e o louvor não são mutuamente excludentes.

O intemporal que a fala de Cassandra sugere para o ouvinte atento da tragédia não é a glória eterna, mas a condição humana, caracterizada por uma mescla de dor e alegria, sendo que essa mistura só é percebida com clareza ao se atribuir à morte seu justo peso. Assim, se a tarefa dos oradores da oração fúnebre é eliminar os traços da condição humana em prol da coragem masculina (Loraux 1994: 345), o discurso de Cassandra, articulado com o restante da tragédia, indica uma visão não parcial da realidade, o que também se verifica nas outras falas da profetisa. Vejamos como isso ocorre nos instantes em que Cassandra se reporta ao divino.

O epitáfio de Cassandra, por certo, não destoa das suas outras intervenções quanto à menção a deuses e a rituais religiosos (376-82; 388-90). Apesar da oração fúnebre ateniense apresentar-se como um discurso laicizado onde o religioso é preterido em favor do político, não é esse o caso do discurso de Cassandra. Todavia, não é tão fácil precisar os contornos da relação entre Cassandra e a esfera dos deuses, esboçada desde o prólogo (41) até o final do primeiro episódio (500-01).

Comecemos pela primeira menção a Cassandra nos versos 41-4. Posêidon sublinha sua virgindade, signo a indicar a ligação entre Cassandra e Apolo, união que no verso 42 também aparece no entrelaçamento dos significantes: "o senhor Apolo repudiou Cassandra, girante” (methêk’ Apollôn dromada Kassandran anax). Uma virgem, Cassandra; um deus, Apolo: isso remete para um contexto familiar aos gregos, o da adivinhação. A adivinhação feita por voz feminina liga-se a Apolo, e a virgindade é traço fundamental dessa mulher (Sissa 1987: 37, 59). 
Mas o verso 42 já prenuncia o rompimento da relação entre Apolo e Cassandra, e parece fazê-lo de modo qualificado, por ser a utilização da forma verbal methêke potencialmente ambígua. O sentido forte do verbo é o de "libertar". Poder-se-ia entender que Apolo liberta Cassandra de sua servidão. Afinal, Cassandra, como Taltíbio no presente, e Hécuba, no futuro - presumível - são servos (latreis: 422, 424, 450). Todavia, ainda que se tratasse de uma libertação, ao se enfatizar certas características presentes de Cassandra (parthenon; dromada), mostra-se que a sua situação não é positiva. Por isso menciona-se a relação - ou seu desmantelamento - entre Cassandra e Apolo antes de se evocar o ato vil de Agamêmnon; as duas situações são unidas assindeticamente (41-3). Dessa forma, parece-me que o sentido do verbo é o de "repudiar". Tal significado o verbo tem em Heródoto IX, 111, onde se menciona um marido repudiando sua esposa; o ato é considerado vil pelo narrador. O que o verbo descreve no verso 42 é o deus voltando suas costas a Cassandra, e, dessa forma, permitindo que ela seja desposada.

Nesse sentido, embora o reproche de Posêidon se dirija claramente a Agamêmnon, creio que seu alvo também - e, talvez, primeiramente - seja mostrar um deus como origem de algo danoso a um seu fiel. Posêidon anuncia o rompimento do "casamento" tranqüilo entre Cassandra e Apolo, e isso, em conjunto com a denominação dromada, indica que intensa desordem atinge a profetisa. ${ }^{8}$

Todavia, na monódia que celebra seu casamento, Cassandra invoca Apolo pacificamente, pretendendo realizar a performance de um ritual. São três os traços mais salientes da performance (canto e dança) de Cassandra: o fogo; a música e a dança; os deuses invocados.

Os primeiros versos da monódia focalizam a tocha brandida, e o duplo assíndeto do verso 308 (“ergue, traz, carrega - venero, alumio...") marca o contexto ritual e o caráter divino da cena. Já se disse que o fogo é o signo característico de Cassandra nessa peça e se sublinhou que ele é uma das imagens que perpassam toda a trilogia de 415 (Scodel 1980: 76-9). Até o início da monódia de Cassandra, já ocorreram diversas menções a "fogo" ou "queimar, fumegar", tanto para descrever danos a atingir os troianos $(8,145)$, quanto para anunciar situações que lhes seriam favoráveis $(60,80,81)$. A enfática presença do fogo na vingança arquitetada por Atena, porém, liga o fogo ao sofrimento por que passarão os gregos, e, quando, no verso 298, Taltíbio teme que as troianas ponham fogo nas próprias vestes, o fogo novamente aparece como algo que pode causar prejuízo aos gregos.

Assim, o fogo que Cassandra traz para o palco seria, à primeira vista, salutar, já que, sobretudo, portador de malefício aos gregos. Todavia, para Hécuba, as 
tochas da filha são funestas e deveriam ser trocadas por lágrimas (342-52). A rainha põe em palavras aquilo que a performance de Cassandra teria provocado nos espectadores de seu ritual: é impróprio para a noiva carregar seu próprio facho; quem o faz é a mãe. Portanto, impõe-se o caráter ambivalente do fogo.

Essa mesma ambivalência é detectada na música e na dança, começando pela alegria presente na monódia, geralmente um canto de lamentação. De fato, os contextos em que a música é mencionada até esse instante da tragédia variam entre positivos (126) e negativos (146-52), sendo que parte de Hécuba a iniciativa de delimitar as fronteiras entre uma música própria a instantes de desgraça e aquela própria a situações de bem-estar, o que, obviamente, não era estranho às práticas gregas e é retomado por Cassandra, ainda que de um modo, no mínimo, chocante (315 e segs.). ${ }^{9}$

Relativamente aos deuses que Cassandra invoca, serão eles inquietantes? Não tanto Hímen, sobre quem, porém, sabemos muito pouco, mas talvez Hécate. Cassandra faz questão de afirmar que a invocação da deusa é feita em um contexto de normatividade (324), mas os intérpretes acreditam que a menção não combina com o resto do canto ou, como Hécate é "mensageira da vingança e da morte" (Sarian 1997: 17), traz conotações sombrias, sobretudo a morte de Cassandra. Ora, o certo é que é muito difícil determinar com precisão as conotações dessa invocação (Harder 1993: 224). Resta-nos formular uma hipótese. O contexto é o do casamento e o principal deus evocado é Apolo; ele é o deus ao qual se liga mais estreitamente Cassandra e é o deus mencionado na antístrofe. Assim parece que Hécate é aqui invocada como o "duplo" de Ártemis (Sarian 1997: 16-17; Burkert 1993: 335), irmã de Apolo. É justamente no século V a. C. que as duas deusas começam a ser identificadas; há, por exemplo, uma menção de Hécate como Ártemis em Fenícias 109. Isso se verifica também na iconografia, onde ambas são portadoras de archotes, justamente o contexto da presente passagem. Além disso, uma série de traços presentes no canto de Cassandra remetem, em conjunto, indiretamente a Ártemis: os coros (325-28), já que Ártemis era honrada com coros por virgens nubentes (Burkert 1993: 298); o próprio casamento (324) (Burkert 1993: 299); a virgindade (Burkert 1993: 297); o fogo e o brilho (Édipo Rei, 206-7).

Outro deus referido é Apolo. Como ele é o deus cuja ligação intrínseca com a princesa já fora estabelecida anteriormente, ele é invocado para afirmar, sobretudo, que a postura de Cassandra é sacra, lícita (329-30). A troiana, que até então fora serva de Apolo, continua a agir conforme os ritos. Apolo liga-se à dança e essa se liga à época afortunada de Príamo (325-28). Ora, Apolo, que tem a dança e o 
canto como área de atuação, também relaciona-se à cura. Mais ainda: o próprio fogo pode ligar-se à sôtêria. Todavia, Apolo não é apenas o deus da lira, mas também do arco. Nesse trecho, porém, ele se encontra vinculado apenas a situações positivas, sendo a violência deixada de lado.

Resta, finalmente, Dioniso. Durante toda a peça, não há nenhuma menção explícita a esse deus, mas Cassandra recebera um grande número de denominações que a vinculam a Baco, sendo que a própria monódia é emoldurada por várias dessas menções $(306,341)$. R. Osborne já mostrou que o menadismo também é explorado nas peças que não são marcadas por um tema dionisíaco claro (Osborne 1997: 192). Em Troianas, o vocabulário dionisíaco usado para descrever Cassandra remete, sobretudo, às evoluções que ela faz na cerimônia de casamento $(169,172$, $307,341-42,349)$. Outro traço de ligação refere-se à possibilidade que experimenta aquele que estiver em transe báquico de prever o futuro. Além disso, o fogo é outro traço que também remete a Dioniso, podendo ser brandido em contextos violentos ou benfazejos.

Fica claro, dessa forma, que Cassandra, na sua performance, utiliza signos que pretende valorar de modo fundamentalmente positivo, procurando uma separação radical entre o salutar e o danoso, o alegre e o triste, o casamento e o luto. Todavia, os signos de que ela faz uso se mostram ambivalentes. Na verdade, as manifestações da troiana revelam que ela procura mostrar que o negativo, na verdade, é positivo. É contra isso que se volta Hécuba no verso 466 ("não é amado o não amado") no início da fala que finaliza o episódio. A aproximação realizada por Cassandra não é inocente. $\mathrm{O}$ que subjaz ao makarismos e é enunciado claramente no início do epitáfio é semelhante ao que gritava o pais amphithalês - a criança filha de pais vivos - nas festas de casamento: "Fugiram do mal, descobriram algo melhor" (Furley 1981: 185). Cassandra procura afastar o danoso descobrindo (nele) algo benéfico.

Ela pretende uma divisão de papéis e de ritos: para a mãe, o luto; para ela, as bodas. Todavia, o ritual do casamento apresenta inúmeros traços em comum com o funeral (Sissa 1987: 107, 129; Seaford: 1987, 107-7; Vermeule 1979: 159). Não se trata apenas da utilização de procedimentos rituais comuns, como a procissão noturna com tochas, mas o próprio imaginário os aproxima. Na arte e literatura gregas, o amor e a morte amiúde aparecem como dois aspectos do mesmo poder. No casamento, a transição da noiva para o seu novo oikos é ambígua, pois os traços apontando para a morte produzem algo inquietante. No final, porém, deve prevalecer a vida. Para Cassandra, vai ocorrer justamente o contrário. 
A primeira tentativa da troiana mostrar que sua situação é positiva fracassa. Assim, ela deixa de utilizar procedimentos rituais e passa a fazer uso da palavra bem-ponderada (365-402). Como vimos, sua palavra é política, mas as menções de destaque são a heróis.

No início da sua fala, Cassandra procura determinar com exatidão qual a sua relação com a divindade. Ela se diz fora de bakkheumata, mas entheos (367). Com isso, não está necessariamente afirmando que, por ocasião do seu canto, estava possuída por Dioniso. O que ela diz é simplesmente que a agitação, manifestada por ocasião da celebração de suas bodas, não mais acompanhará sua fala. Por isso enfatiza que é entheos: ela se encontra sob a esfera de ação de Apolo, e isso ecoará num discurso que Cassandra pretenderá claro. Que nada é menos claro, isso já mostramos. Cassandra, à medida que determina, ela mesma, sua relação com o divino, apresenta-se como autora de previsões futuras, embora suas previsões sejam de "segunda mão" (428-30); ela constrói seu próprio texto. Em relação a Apolo, ela deixa de ser aquilo que, para Aristóteles, a mulher significava para o homem: um mero substrato (Sissa 1987: 57). Cassandra apresenta-se muito mais como homem.

Mas a fala mais estarrecedora da profetisa são os tetrâmetros trocaicos que encerram sua participação. Os versos epitomam seu futuro, a conquista da glória com a própria morte. Mas eles encerram - por parte de Cassandra - um dado novo, a sua desvinculação de Apolo. Aquela que vai conquistar a vitória (460) perde suas coroas (451). Depois de solicitar a coroa que cabe à noiva como se fosse a coroa que mereceria o vitorioso em um agôn (353-64), essa mesma coroa se mostra apropriada a um defunto, ainda que defunto vencedor. Isso, porém, é referido no instante mesmo em que Cassandra se desvencilha das coroas que marcaram sua relação especial com Apolo. No lugar das coroas apropriadas ao vencedor, à noiva e à sacerdotisa, as coroas que cabem ao defunto.

Mas por que Cassandra arranca seus paramentos? A separação é tranqüila ou problemática? Consegue-se um esboço de resposta comparando-se o trecho com uma passagem correspondente em Agamêmnon (1264-70). A diferença é clara. Em Ésquilo, Cassandra se livra dos seus enfeites de modo violento e figura o deus como aquele que a despe, ao mesmo tempo em que menciona que sua tarefa como profetisa foi inútil e risível. Em Troianas, Cassandra sente necessidade de se livrar dos paramentos para ela mesma se tornar outra.

Esse estado outro de Cassandra é a morte ou a perda da virgindade? No seu futuro, destaca-se a morte; a morte precede suas "bodas" (445). Desse modo, pa- 
rece que se enfatiza que Apolo e Cassandra se separam porque ele é um apenthês theos que não aceita trenos e não entra em contato com a morte (Fränkel 1950: ad 1075). Em Alceste 22, Apolo diz que deve abandonar a casa de Admeto para que o miasma, que vem com Morte, não o alcance. Na verdade, porém, manterem-se afastados da morte é próprio dos deuses. Ainda assim, a morte do fiel não implica um afastamento radical do deus. O final do Hipólito é exemplar: Ártemis não pode olhar a morte (1437-38) e não pode chorar, mas vai continuar a amar seu fiel (1396 e segs.). Não é na morte tout court que devemos, portanto, procurar as razões do rompimento entre Cassandra e Apolo.

O contexto é o de um funeral, embora se destaque o casamento. No funeral, o cadáver recebe uma vestimenta. Cassandra, porém, irá nua para sua "cova". Além disso, ainda antes irá se desvencilhar de seus paramentos por meio de sparagmoi. Esse termo também está em oposição ao mundo de Apolo. Em certas passagens, ele ilustra o desespero de mulheres enlutadas, como em Hécuba 650-56. O trecho de Troianas indica que os gestos de Cassandra se assemelham ao luto ritual. Cassandra prefigura as próprias carpideiras, já que não terá um enterro de acordo com os ritos. Mas o trecho mais interessante para o nosso contexto é Fenícias 1485 e segs., onde Antígona procede a lamentações fúnebres como uma bacante (1489), rasgando seus cabelos com sparagmoi (1525). A laceração de Cassandra, por sua vez, é dupla. Ela se completa no ambiente selvagem que lhe vai servir de cova.

Os deuses que mais se vinculam ao ambiente selvagem são Dioniso e Ártemis. Dioniso propicia uma "comunhão com a natureza selvagem" (Vernant 1991: 250), e Ártemis é basicamente ligada à caça (Burkert 1993: 295-96). Na passagem que nos interessa, porém, eles aparecem - sem serem nomeados diretamente, é bem verdade - sob sua face negativa. $\mathrm{O}$ dois deuses foram evocados anteriormente por Cassandra, mas o cenário agora é outro. Cassandra aparece aqui como uma mênade (mainas, 172 e 307) que é vítima do mundo selvagem, quando dele deveria fazer uso a seu bel-prazer. Nas Bacas, por exemplo, a bacante "moderada" não é destruída, como mostram os versos 314 e segs.

Além disso, Cassandra figura-se como a Erínia (457) que fará com que a casa de Atreu purgue as mortes ocorridas em Tróia (460-61). Em Agamêmnon, a Erínia vingadora é associada a Clitemnestra (1114-1120), vinculação potencializada nas Eumênides. Quanto a Troianas, Cassandra não pode dizer-se uma Erínia qua vingadora de matricídio, pois afirma ser, ela mesma, a causa do assassinato de Clitemnestra (363-64). As Erínias mencionadas por Cassandra parecem ser Páris, Heitor e ela própria. 
Para uma percepção do alcance da afirmação de Cassandra, deve-se partir de uma passagem das Eumênides de Ésquilo. No prólogo dessa tragédia, Apolo reitera que, embora Orestes tenha se conspurcado com um crime, jamais deixará de protegê-lo (61 e segs.), já que foi o próprio Apolo que lhe ordenou que assassinasse sua mãe. Mas se Apolo não se afasta de Orestes, igual procedimento ele evita em relação às Erínias. Odiadas por todos, com elas nem deus, nem homem, nem fera entram em contato $(69-70,73)$, pois estão sempre próximas daquilo que é vil, kakos, habitando inclusive o kakos skotos, ou seja, o Hades. Vale notar, aliás, que, em Troianas, por duas vezes as bodas de Cassandra são descritas como "escuras", ou seja, "escusas" (skotios, 44, 252). Cassandra, assim, fazendo-se Erínia, potencializa seu afastamento de Apolo. De forma semelhante àquilo que se afirma das Erínias em Eumênides 75-7, Cassandra persegue implacavelmente, sem nenhum retardo, a sua vítima, Agamêmnon $(342,455-57)$. Ela deixa de ser uma profetisa ideal; cria, escolhe suas próprias palavras em um casamento corrompido, ligado à morte e à vingança.

Posêidon se despede de Tróia (45); Cassandra se despede dos laços que a uniam a Apolo (452). Posêidon anuncia o afastamento de Apolo em relação a Cassandra; Cassandra não apenas assume esse afastamento, mas lhe dá uma configuração própria, potencializando-o. Para Posêidon, é Apolo que abandona Cassandra; segundo a perspectiva de Cassandra, ela mesma abandona Apolo.

Com isso não se está apenas enfatizando a manutenção de uma situação típica do imaginário grego - a separação entre os deuses e os homens -, nem se está apenas mostrando uma face própria de Apolo, o afastamento entre os mortais e os imortais como algo que embasa uma das máximas de Delfos, o "conhece-te a ti mesmo". O que o episódio de Cassandra, visto como um todo, reflete é a posição possível do herói entre o mundo da cidade e a esfera divina. Ele não pertence a nenhum dos dois, mas carece de ambos para mostrar sua força e revelar seus limites.

Vimos como o principal problema do epitáfio enunciado pela profetisa é a ausência de Tróia; o problema do seu casamento vingativo, por sua vez, é o que ele provoca na sua relação com o divino. A solução que Cassandra apresenta para ambos os problemas é a glória imortal, própria do herói, ou seja, ela se posiciona a si mesma no centro do seu discurso, deslocando a cidade e os deuses para uma posição periférica, embora façam parte da totalidade que ela esboça. A glória, porém, só pôde ser invocada à medida que a cidade foi destruída e os deuses mostraram um seu lado destrutivo; ela independe, portanto, em grande parte, do valor do próprio indivíduo. Ainda assim, o que parece restar àquele indivíduo que se vê 
afastado de uma cidade e de seus deuses é apenas gerir esse afastamento com as próprias mãos. A morte desonrosa de Cassandra aponta para os limites da cidade e da relação homem-deus, ambos não sendo eternos; todavia, a glória também não garante ao indivíduo uma posição de destaque em relação à cidade e aos deuses.

A própria Cassandra não se afastou irremediavelmente da polis. Sob a iminência de uma morte ultrajante que lhe negaria qualquer tipo de cerimônia fúnebre, volta-se para uma situação diametralmente oposta, realizando seu elogio fúnebre antes que a morte ocorra; da mesma forma, foi somente o contato privilegiado com Apolo que lhe permitiu vislumbrar seu futuro, base do epitáfio enunciado antes do tempo. No final, porém, o que confere a última palavra é a morte: ela mostra a outra face da ação, o sofrimento; ela indica que no mundo da cultura também vale uma máxima da natureza, a que tudo o que cresce, perece, máxima que a Atenas clássica tenta purgar a todo custo de um texto ideologicamente marcado como a oração fúnebre.

O coro, no estásimo que segue a essa cena, ao pedir à Musa "cantos novos", retratando instantes em que à máxima alegria se sucede a desgraça máxima (a noite em que o cavalo de pau foi introduzido na cidade), reforça o quadro inaugurado por Cassandra. A primeira vista, os troianos parecem ter procedido de modo oposto à profetisa: colocaram a cidade e os deuses em primeiro lugar; eles apenas seriam beneficiários da glória alheia. Entretanto, no bojo do regozijo irrompeu o sofrimento.

\section{Notas}

* Prof. Dr. do PPG Letras Clássicas e do Curso de Graduação em Letras da FFLCH/USP.

1 Para uma bem documentada e arguta discussão da recepção de Eurípides na modernidade, em especial, pela filologia alemã do século XIX, bem como de sua reconsideração no século XX, cf. Coelho (2001: 100-36).

2 Dois exemplos radicais dessas correntes são Meier (1991) e Heath (1987); tal impasse metodológico foi discutido por mim em Werner 2004 utilizando uma tragédia de Sófocles, o Ájax.

3 Acerca da oração fúnebre ateniense, cf. Loraux (1994); sobre o seu caráter monológico, cf. p. 107. A autora busca uma descrição dessa prática social, da qual chegaram, até nós, como testemunhos, além dos discursos de Lísias, Demóstenes e Hipérides (fragmentos), a "reconstrução" do epitáfio de Péricles por Tucídides e o diálogo platônico Menexeno, bem como pequeno um pequeno fragmento do epitáfio de Górgias.

4 Nesse sentido, a tragédia é legítima herdeira da épica (confira, por exemplo, a sucessão de falas que compõe o primeiro canto da Ilíada). Polemicamente, o título de um dos capítulos do livro de Lynn-George (1988) é "The epic theatre"; o autor refere-se do 
seguinte modo à concepção da épica como tragédia avant la lettre: "This conception of drama 'before its time' was ultimately to be construed as the deficiency in the epic's dramatic art when compared to the Attic tragedy which followed” (p. 50). O vício do evolucionismo é uma praga que ainda não abandonou boa parte das interpretações de textos clássicos.

5 A tradução de Troianas utilizada é a de Eurípides (2004).

6 Acerca das complexas relações entre Apolo e Dioniso, cf. Detienne (2001); no que diz respeito a "la pleureuse de Loxias et la bacchante d'Apollon", tanto em Troianas, quanto em Agamêmnon de Ésquilo, cf. Loraux (1999: 112-19).

7 Para o inter-relacionamento entre oikos e polis, veja, por exemplo, Sólon, 4W, para quem o desejo de riqueza dos indivíduos particulares traz dano a toda a cidade, de sorte que o mal acaba penetrando nas casas de todos os cidadãos. Em Tirteu, 10W, anuncia-se que é nobre morrer pela cidade, e o mais vergonhoso é não lutar e perder seu oikos, vagando como um mendigo.

8 Sissa (1987: 53) mostra que a alma da Pítia, dócil à persuasão do deus, assemelha-se à jovem esposa, guiada pelo marido. Todavia, os oráculos tornam-se duvidosos e errôneos se é a alma humana que toma a iniciativa ou se o corpo da pitonisa passa a agir (Jâmblico, de mysteriis, III, 7, apud Sissa 1987: 55).

9 Acerca da música como elemento temático e, portanto, auto-referencial da tragédia (e não somente um dos seus elementos de expressão), cf. Loraux (1999: passim).

\section{REFERÊNCIAS BiBLIOGRÁFICAS}

BURKERT, W. (1993) Religião grega na época clássica e arcaica. Lisboa: Fundação Calouste Gulbenkian.

COELHO, M. C. de M. N. (2001) Eurípides, Helena, e a demarcação entre retórica e filosofia. São Paulo. (tese de doutorado, inédita)

DETIENNE, M. (2001) "Forgetting Delphi between Apollo and Dionysos". CP 96: $147-58$.

EURÍPIDES. (2004) Duas tragédias gregas: Hécuba e Troianas. Tradução e introdução: Christian Werner. São Paulo.

FRAENKEL, E. (1950) Aeschylus: Agamemnon. 3 vol. Oxford.

FURLEY, W. D. (1981) Studies in the Use of Fire in Ancient Greek Religion. Salem.

HARDER, R.E. (1993) Die Frauenrollen bei Euripides. Untersuchungen zu Alkestis, Medeia, Hekabe, Erechteus, Elektra, Troades und Iphigenia in Aulis. Stuttgart.

HEATH, M. (1987) The Poetics of Greek Tragedy. London

LESKY, A. (1995) A história da literatura grega. Lisboa. 
LORAUX, N. (1994) Invenção de Atenas. São Paulo. . (1999) La voix endeuillée: essai sur la tragédie grecque. Paris.

LYNN-GEORGE, M. (1988) Epos: Word, Narrative and the Iliad. London.

MASON, P. (1959) "Kassandra”. JHS 79: 80-93.

MEIER, C. (1991) De la tragédie grecque comme art politique. Paris.

OSBORNE, R. (1997) "The ecstasy and the tragedy: varieties of religious experience in art, drama, and society”. In: PELLING, C. Greek Tragedy and the Historian. Oxford.

SARIAN, H. (1997) "Hécate duplo de Ártemis. Uma interpretação da cratera ática de Toronto". Boletim do CPA 4: 15-22.

SCODEL, R. (1980) The Trojan Trilogy of Euripides. Göttingen.

SEAFORD, R. A. S. (1987) "The tragic wedding". JHS 107: 106-31.

SISSA, G. (1987) Le corps virginal. Paris.

VERMEULE, E. (1979) Aspects of Death in Early Greek Art and Poetry. Berkeley; Los Angeles.

VERNANT, J.-P. (1989) L'individu, la mort, l'amour. Paris.

VERNANT, J.-P.; VIDAL-NAQUET, P. (1991) Mito e tragédia na Grécia antiga II. São Paulo.

WERNER, C. (1999) Troianas, de Eurípides: estudo e tradução. São Paulo. (dissertação de mestrado, inédita) $141-57$.

. (2004) "A arbitrariedade do sentido e do poder em Ájax 1047-1162". Phaos 4:

\section{INFORME}

O texto acima, em outra versão, foi o capítulo inicial da minha dissertação de mestrado, defendida em 1999 na Universidade de São Paulo. Agradeço, pelas sugestões e discussões, à minha orientadora, Filomena Yoshie Hirata (FFLCH/ USP), e a Maria Cecília Miranda Nogueira de Coelho (COGEAE/PUCSP).

WERNER, Christian. Cassandra's performances in Euripides' Troades.

ABSTRACT: In the $5^{\text {th }}$ century $b$. C., there is in Athens a distance between political speeches, like the funeral oration, and the tragic discourse, 
but that difference has been effaced in the last decades in many critical works on tragedy. The episode of Cassandra in Euripides Troades is a good example to show quite the opposite: the use of the ideology of the polis by a tragedy to make clear the otherness of the tragic discourse. Cassandra moves between an attempt to build a consistent speech about the eternal glory of Troy and the performance of her own marriage, which links her to the vicissitudes of her family and her own story as a prophetess.

KEY WORDS: tragedy; Euripides; Troades; funeral oration. 